middel, want krachtens arresten d.d. 26 Februari 1919 (B. 2160) en d.d. 4 November 1931 (B. 5072) mag bij pleidooi geen nieuw cassatiemiddel worden aangevoerd.

Het fiscale procesrecht staat gelijk bekend op de helling; hopelijk wordt daarbij aandacht geschonken aan de termijnen, die m.i. wel wat verlengd mogen worden.

Volledigheidshalve zij nog gewezen op een eigenaardige consequentie. Wil men er verzekerd van zijn, dat de Raad van Beroep op de aanvulling van het beroepschrift acht zal slaan, dan moet het tijdig ingediende (formele) beroepschrift onvolledig zijn!

Zo oordeelde de H. R. bij arrest van 22 October 1941 (B. 7381), dat de R. v. B. geen wetsartikel schond, door op een aanvullend beroepschrift (waarin een nieuwe grief was verwerkt) geen acht te slaan.

Bij zijn arresten van 2 Maart 1949 (B. 8575) en van 4 Januari 1950 (B. 8717). overwoog de H. R., dat de omstandigheid dat de belanghebbende een bezwaar dat een feitelijk argument bevat, niet in het beroepschrift doch eerst bij de mondelinge behandeling naar voren heeft gebracht, de R. v. B. niet mag weerhouden het in behandeling te nemen, tenzij het redelijkerwijs ook reeds bij het beroepschrift had kunnen zijn aangevoerd en bovendien behandeling ervan de Inspecteur in ernstige mate in de verdediging van de aanslag zou belemmeren.

Misschien mag uit het arrest van 18 Maart j.l. worden opgemaakt, dat de H.R. thans iets milder t.a.v. een na een volledig beroepschrift ingediend aanvullend beroepschrift oordeelt, maar voorshands doet men goed in het belang van zijn cliënten het arrest van 22 October 1941 in zijn gedachten te houden.

\title{
KOSTEN ACCOUNTANTSSTUDIE GEEN KOSTEN VAN VERWERVING
}

\section{door Mr Dr E. Tekenbroek}

In zijn arrest van 25 December 1952 beantwoordde de H. R. de vraag of de studiekosten, die een assistent-accountant zich getroost voor het behalen van zijn accountantsdiploma, als kosten van verwerving van zijn salaris kunnen gelden.

De Hoge Raad overwoog:

„dat de Raad van Beroep feitelijk heeft beslist, dat niet gebleken is, ,,dat belanghebbende, zou hij in Augustus 1950 niet hebben gestu„,deerd, ongeschikt zou zijn geweest voor een behoorlijke vervulling .van werkzaamheden, die behoorden tot de functie, die hij toen „,bekleedde, zij het ook, dat hij wellicht niet alle tot die functie te „,rekenen werkzaamheden zou hebben kunnen verrichten;

",dat de Raad hiermede klaarblijkelijk heeft bedoeld tot uitdruk,king te brengen, dat hem niet de overtuiging is geschonken, dat ,belanghebbende in 1950, zo hij zijn studie voor accountant niet ,zou hebben voortgezet, voor zijn werkgeefster niet een bruikbare „kracht zou zijn geweest in de rang, die hij toen bekleedde;

,"dat de Raad van Beroep voorts als zijn feitelijk oordeel heeft .,gegeven, dat voor assistenten de grootste drijfveer tot hun studie 
",moet worden gezocht in hun verlangen het accountantsdiploma te ,,behalen;

„dat, een en ander in aanmerking genomen, belanghebbendes uit.gaven voor zijn accountantsstudie in 1950 geen kosten zijn, welke ,,belanghebbende noodwendig moet maken om zijn dienstbetrek.,king naar behoren te kunnen vervullen, doch kosten, welke hij zich "getroost om in de toekomst een betere positie te verkrijgen;

.dat de Raad van Beroep dan ook terecht die uitgaven niet als .,kosten tot verwerving van het loon heeft aangemerkt".

Een soortgelijk arrest had de H. R. d.d. 10 October 1951 (B. 9086) gewezen met betrekking tot de kosten, die een boekhouder maakte voor het volgen van een cursus moderne bedrijfsadministratie. De R. v. B. had feitelijk vastgesteld, dat die studie geen zakelijk verband hield met de dienstbetrekking, zodat de kosten ervan niet aftrekbaar werden geoordeeld.

Gunstiger voor de belastingplichtige was het arrest van 11 Januari 1950 (B. 8720). Hierin besliste de H. R., weer afgaande op de feitelijke vaststelling van de R. v. B., dat de kosten gemaakt door een ambtenaar ter gemeentesecretarie voor het volgen van een cursus voor gemeentefinanciën wel aftrekbaar zijn, omdat die studie noodzakelijk werd geoordeeld om de in de werkkring opgedragen werkzaamheden naar behoren te kunnen verrichten en dus niet strekte om in de toekomst een betere positie te verkrijgen.

Uit al deze arresten blijkt. dat de feitelijke beslissing van de Raad van Beroep predomineert.

Men zou een en ander globaal als volgt kunnen samenvatten:

Opleidingskosten mogen niet worden afgetrokken. De mate waarin de totale kosten, die een assistent maakt voor zijn studie, te splitsen zijn in niet aftrekbare opleidingskosten en wel aftrekbare overige kosten, is een feitelijke kwestie. Het ligt in de lijn van de jurisprudentie, dat een eerste assistent andere studiekosten mag aftrekken dan een derde assistent, omdat door verschil in werkzaamheden van de eerste assistent, de studie die nodig is om hem in staat te stellen zijn werkzaamheden goed te kunnen verrichten, van andere aard zal zijn dan de studie van de derde assistent.

Het lijkt mij intussen zeer waarschijnlijk dat van de zijde van de fiscus het verweer zal worden gevoerd, dat aangenomen moet worden dat men niet tot assistent (derde, tweede of eerste) aangesteld zal worden, als men niet reeds de studie om de desbetreffende werkzaamheden goed te verrichten, achter de rug heeft.

In verband met de hierboven afgedrukte bewoording van het arrest, staat m.i. de fiscus met dit verweer zeer sterk. Praktisch betekent een en ander, dat de kans op aftrek van studiekosten voor de assistent-accountants minimaal moet worden geacht. 